\title{
Antibiotic dosages and abuse in dentistry
}

\author{
Aditi Sharma $^{1}$, Akshat Sachdeva ${ }^{2}$, Sumit Bhateja ${ }^{3, *}$, Geetika Arora $^{4}$ \\ ${ }^{\mathbf{1 , 2}}$ Dental Surgeon, ${ }^{\mathbf{3}, 4}$ Reader, ${ }^{\mathbf{3}}$ Dept. of Oral Medicine and Radiology, ${ }^{\mathbf{4}}$ Dept. of Public Health Dentistry, ${ }^{\mathbf{1 , 2 , 3}}$ Manav Rachna \\ Dental College, Faridabad, Haryana, ${ }^{4}$ Indraprastha Dental College, Ghaziabad, Uttar Pradesh, India
}

*Corresponding Author:

Email: bhateja.sumit@gmail.com

\begin{abstract}
Dental health care professionals prescribe antimicrobial agents for conditions both therapeutically and prophylactically. These antimicrobials are given prophylactically before dental procedures, during treatments, after treatment or as the only form of treatment. . Many patients going through the hardship of dental pain visit the dentist only to get a prescription for the same which is very often inclusive of an antimicrobial agent without getting any treatment done. In developing countries like India, where law regarding the prescription of antimicrobials is not very strong or is not strongly implemented, people just visit a neighborhood pharmaceutical store to purchase medicines over the counter for dental pain, which again includes antimicrobial agents. This cycle is repeated numerous times before the person finally decides to get definitive dental treatment done.

The present article focuses on Antibiotic usages \& abuses in dental practice.
\end{abstract}

Keywords: Antibiotic, Dentistry, Abuse.

\section{Introduction}

The Word "Antibiotic" ineluctably pops in our minds whenever an infection has to be dealt with. Dentists recommend medications for management of many oral conditions mainly orofacial infections. But this certitude cannot be regretted that there is a worldwide abuse of antibiotics in medical as well as dental profession.

Dentists commonly prescribe antibiotics for not only treating but also controlling dental infections. But there is a widespread abuse of antimicrobials in medical and dental profession. The indecorous use of antibiotics results in increased financial expenses, increased menace of adverse events related to the antibiotic used and most significantly development of antimicrobial resistance.

The abuse of antibiotics does not necessarily mean that they may be unnecessary, but side effects may be more fatal than the original concern. This is especially true regarding the field of dentistry, where infections are rarely serious. Despite these problems associated with antibiotic use, antibiotics are used as an essential weapon against infection; hence use of antibiotics requires the clinician to take the stance that positive indication must be present before antibiotic drugs are prescribed. The clinician should not assume that antibiotics must be given in all instances of infection. ${ }^{1}$

\section{Classification of anti - microbial drugs}

Although there are many systems for classification, the most useful is based on chemical structure. Antibiotics within a structural class will generally have similar patterns of effectiveness, toxicity, and allergic potential.

The chief classes of antibiotics are: ${ }^{2}$
1. Beta-Lactams

2. Penicillins

3. Cephalosporins

4. Macrolides

5. Fluoroquinolones

6. Tetracyclines

7. Aminoglycosides

Most commonly used antibiotics are: Aminoglycosides, Penicillins, Fluoroquinolones, Cephalosporins, macrolides, and Tetracyclines. While each class consists of multiple drugs, each drug is peculiar in its own way.

\section{Principles of drug usage}

In a short span of time, antimicrobial governance has been given lot of influence not only at the patient but also at the community level. Antimicrobial governance is defined as "the optimal selection, dosage, and duration of antimicrobial treatment that results in the best clinical outcome for the treatment or prevention of infection, with minimal toxicity to the patient and minimal impact on subsequent resistance." Joseph and Rodvold $^{3}$ stated the 4 D's of antimicrobial therapy which are correct Drug, correct Dose, De-escalation to pathogen associated therapy and right Duration of therapy. An important consideration in commencing antimicrobial therapy is the evaluation of the infection and if the patient has a sufficient immune response to control the pathogenic bacteria. In cases of purulence, signs of inflammation, abscess or draining sinus tracts, the lesion/infection respond to local debridement measures in a healthy patient. In an otherwise healthy patient, infections that have not passed over the dento alveolar regions are liable to treatment without anti microbial remedy. ${ }^{4}$ 
Antibiotics useful in dental practice ${ }^{5}$

\begin{tabular}{|c|c|c|c|}
\hline Antibiotics Used & Nature & Dosages & Side Effects \\
\hline Amoxicillin & Bactericidal & $\begin{array}{l}500 \mathrm{mg} / 8 \text { hours } \\
1000 \mathrm{mg} / 12 \text { hours }\end{array}$ & $\begin{array}{l}\text { Diarrhea, nausea, } \\
\text { hypersensitivity } \\
\text { reactions }\end{array}$ \\
\hline Cephalosporins & Bactericidal & $250-500 \mathrm{mg} / 8$ hours & $\begin{array}{l}\text { Black tarry stools, } \\
\text { chills, cough, pyrexia. }\end{array}$ \\
\hline $\begin{array}{l}\text { Amoxicillin+ } \\
\text { Clavulanate }\end{array}$ & Bactericidal & $\begin{array}{l}500-875 \mathrm{mg} / 8 \text { hours; } \\
\text { oral route } \\
2000 \mathrm{mg} / 12 \text { hours; } \\
\text { oral route } \\
1000-2000 \mathrm{mg} / 8 \text { hours; } \\
\text { intravenous route }\end{array}$ & $\begin{array}{l}\text { Diarrhea, candidiasis, } \\
\text { nausea, } \\
\text { hypersensitivity } \\
\text { reactions }\end{array}$ \\
\hline Metronidazole & Bactericidal & $500-750 \mathrm{mg} / 8$ hours & $\begin{array}{l}\text { Seizures, paresthesia } \\
\text { of limbs, incompatible } \\
\text { with alcohol ingestion }\end{array}$ \\
\hline Tetracyclines & Bacteriostatic & $500 \mathrm{mg} / 6$ hours & $\begin{array}{l}\text { increased sensitivity to } \\
\text { sunlight, abdominal } \\
\text { discomfort, loss of } \\
\text { ravenousness }\end{array}$ \\
\hline Clindamycin & Bacteriostatic & $\begin{array}{l}300 \mathrm{mg} / 8 \text { hours; oral } \\
\text { route } \\
600 \mathrm{mg} / 8 \text { hours; } \\
\text { intravenous route }\end{array}$ & $\begin{array}{l}\text { Pseudomembranous } \\
\text { colitis }\end{array}$ \\
\hline $\begin{array}{l}\text { Gentamicin } \\
\text { (Aminoglycoside) }\end{array}$ & $\begin{array}{l}\text { Bactericidal/ } \\
\text { Bacteriostatic }\end{array}$ & $240 \mathrm{mg} / 24$ hours & $\begin{array}{l}\text { Ototoxicity } \\
\text { Nephrotoxicity }\end{array}$ \\
\hline Azithromycin & Bacteriostatic & $500 \mathrm{mg} / 24$ hours & $\begin{array}{l}\text { Diarrhea, loose stools, } \\
\text { irritation on skin }\end{array}$ \\
\hline Ciprofloxacin & Bactericidal & $500 \mathrm{mg} / 12$ hours & $\begin{array}{l}\text { Pyelonephritis, } \\
\text { arthralgia, diarrhea }\end{array}$ \\
\hline Penicillin & Bactericidal & $\begin{array}{l}1.2-2.4 \text { million IU/24 } \\
\text { hours; intramuscular } \\
\text { route } \\
\text { Up to } 24 \text { million } \\
\text { IU/24hours; } \\
\text { intravenous route }\end{array}$ & $\begin{array}{l}\text { Hypersensitivity } \\
\text { reactions, gastric } \\
\text { alterations }\end{array}$ \\
\hline
\end{tabular}

\section{Antibiotic Abuse}

The evolution and widespread adoption of "antibiotics"- drugs that kill pathogenic bacteria and thereby diminish contamination - has helped millions of people live longer and healthier lives. But all this fiddling with nature has cost us a lot. The more we depend on antibiotics, the more bacterial resistance is being developed, which is now a days the biggest challenge to treat infections.

The last type of prescription is very common in developing countries where a big proportion of population cannot afford dental treatment in private dental setups and the government facilities for the same are limited and over - populated. Many patients going through the hardship of dental pain visit the dentist only to get a prescription for the same which is very often inclusive of an antimicrobial agent without getting any treatment done. In developing countries like India, where law regarding the prescription of antimicrobials is not very strong or is not strongly implemented, people just visit a neighborhood pharmaceutical store to purchase medicines over the counter for dental pain, which again includes antimicrobial agents. This cycle is repeated numerous times before the person finally decides to get definitive dental treatment done. ${ }^{6}$

Given below are some risks that have been shown to be associated with overuse of antibiotics: ${ }^{7}$

1. Increase of antimicrobial resistance.

2. Increase of more potent diseases.

3. Increase of longevity of disease.

4. Increase in risk of complications.

5. Increase in mortality rate.

6. Increase in healthcare costs.

7. Increase of risk of adverse effects, some being lifethreatening.

Most commonly, antimicrobial abuse is observed amongst those patients who use prophylactic antimicrobials before dental procedures for the prevention of post-operative complications like dry socket or to prevent systemic complications. ${ }^{8}$ Studies 
have elicited that the endodontic procedures involve the widespread prescription of inter appointment antimicrobials. ${ }^{9}$

It is not mandatory to prescribe antibiotics in all circumstances. Given below is a list of certain conditions that we commonly face in our dental practice, with the treatment modalities and whether to prescribe antibiotics or not: ${ }^{10,11}$

\begin{tabular}{|c|c|c|}
\hline Condition & Treatment approach & Antibiotics needed \\
\hline $\begin{array}{l}\text { Uncomplicated endodontic } \\
\text { pathology }\end{array}$ & - Debridement of root canal & No \\
\hline $\begin{array}{l}\text { Soft tissue inflammation of } \\
\text { endodontic origin }\end{array}$ & $\begin{array}{l}\text { - Debridement of root canal } \\
\text { - Incision and drainage. }\end{array}$ & No \\
\hline $\begin{array}{l}\text { Endodontic pathology confined to } \\
\text { the alveolar bone }\end{array}$ & $\begin{array}{l}\text {-Trephination of bone to } \\
\text { alleviate pressure } \\
\text { and accelerate healing }\end{array}$ & No \\
\hline Periodontal abscess & $\begin{array}{l}\text { - Scaling } \\
\text { - Drainage of suppuration }\end{array}$ & No \\
\hline Chronic periodontitis/ Gingivitis & Scaling and root planing & No \\
\hline $\begin{array}{l}\text { NUG without systemic } \\
\text { complications in } \\
\text { salubrious individuals }\end{array}$ & $\begin{array}{l}\text { - Debridement } \\
\text { - Irrigation } \\
\text { - Scaling and root planing }\end{array}$ & No \\
\hline $\begin{array}{l}\text { NUG with systemic complications } \\
\text { or in } \\
\text { immunocompromised individual / } \\
\text { HIV } \\
\text { associated NUG/NUP }\end{array}$ & $\begin{array}{l}\text {-Debridement } \\
\text {-Irrigation } \\
\text {-Scaling and root planing } \\
\text {-Systemic Antibiotic } \\
\text { Therapy }\end{array}$ & $\begin{array}{l}\text { Yes. Metronidazole is } \\
\text { primary drug. } \\
\text { Penicillin group of drugs } \\
\text { may be } \\
\text { an accessory choice [35] }\end{array}$ \\
\hline $\begin{array}{l}\text { Aggressive periodontal diseases / } \\
\text { Refractory } \\
\text { periodontal conditions }\end{array}$ & $\begin{array}{l}\text { - Debridement } \\
\text { - Scaling and root planning }\end{array}$ & $\begin{array}{l}\text { May be required in early } \\
\text { cases of } \\
\text { generalized aggressive } \\
\text { periodontitis }\end{array}$ \\
\hline Localized abscess & $\begin{array}{l}\text { - Incision and Drainage } \\
\text { - Removal of source of } \\
\text { infection }\end{array}$ & No \\
\hline Facial space infections & $\begin{array}{l}\text { - Incision and drainage } \\
\text { - Removal of pivot of } \\
\text { infection }\end{array}$ & Yes \\
\hline $\begin{array}{l}\text { Complicated endodontic/ } \\
\text { periodontic } \\
\text { pathology with signs of systemic } \\
\text { spread of } \\
\text { infection /involvement of facial } \\
\text { spaces }\end{array}$ & $\begin{array}{l}\text { - Removal of source of } \\
\text { infection } \\
\text { - Incision and drainage }\end{array}$ & Yes \\
\hline $\begin{array}{l}\text { Systemically compromised } \\
\text { individuals with } \\
\text { immune defects }\end{array}$ & $\begin{array}{l}\text { Removal of source of } \\
\text { infection }\end{array}$ & $\begin{array}{l}\text { Yes (use of bactericidal } \\
\text { drugs } \\
\text { recommended) }\end{array}$ \\
\hline $\begin{array}{l}\text { Before uncomplicated/ } \\
\text { complicated } \\
\text { Extractions }\end{array}$ & - & No \\
\hline Before to perio/endo surgeries & - & No \\
\hline $\begin{array}{l}\text { Before Regenerative periodontal } \\
\text { therapy } \\
\text { with membranes / grafting }\end{array}$ & - & May Be \\
\hline Before implant surgery & - & $\begin{array}{l}\text { Yes (use of bactericidal } \\
\text { drugs } \\
\text { recommended) }\end{array}$ \\
\hline
\end{tabular}




\section{Future Steps}

Reducing inappropriate antibiotic use is only one part of the solution. The antibiotics we have must be conserved while we explore new rapid diagnostics and unorthodox antimicrobials. Effective hygiene and infection control must also be given equal priority. Both human and animal health sectors should be worked upon and taken into consideration so that the human health is bridged to the health of animals and the environment. This includes working with all health professionals, their concerned agencies, and their enforcement arms. This is known as the 'One Health' approach and it is the core master plan on antimicrobial resistance. ${ }^{12}$

What measures can we as dentists take to prescribe antibiotics efficiently? Our aim should be to promote a rational use of antibiotics and not only to lessen the amount of antibiotics while prescribing them to the patient. Educational campaigns have been regulated in many countries with the goal to transfigure healthcare professional as well as patient behavior in antibiotic consumption. Interventions include the dissemination of specifications, educational gatherings on appropriate prescribing of antibiotics, concourse on the diagnosis, prevention and management of infectious diseases, review of prescribing data for practices, local interviews by pharmacists, memorandums conveyed through television, radio and other means of mass media. ${ }^{7}$

We must find ingenious ways to reduce antimicrobial abuse. We being the future healthcare professionals should take a pledge to implement ethical practice and prescribe antibiotics in conditions when really necessary, and we should encourage patients to self-manage minor infections and deplete reliance on antimicrobials. As a society we need to acknowledge that antibiotics are rudimentary to how we practice modern medicine. We must value them as per the need.

\section{Conclusion}

Most odontogenic contagions are manageable by elimination of the primary cause of infection. Felicitous antibiotic organization and rational prescription of antibiotics by dentists is the need of the hour in view of the epidemic concern of antimicrobial resistance. The basic foundation to fight against antibiotic abuse is "education" which should be imparted not only during the training phase but also while practicing in dental setups.

\section{References}

1. Pharmacology by K.D. Tripati 5 th edition.

2. http://www.emedexpert.com/classes/antibiotics.shtml\#3

3. Joseph J, Rodvold KA. The role of carbapenems in the treatment of severe nosocomial respiratory tract infections. Expert Opin. Pharmacother. 2008; 9:561-75.

4. Newman MG, Winkelhoff AJ van. Antibiotic and antimicrobial use in dental practice. Quintessence Pub Co.; 2001.
5. Poveda-Roda R, Bagán JV, Sanchis-Bielsa JM, CarbonellPastor E. Antibiotic use in dental practice. A review. Med Oral Patol Oral Cir Bucal 2007;12:E186-92.

6. Cleveland JI, Kohn WC, Antimicrobial resistance and dental care: A CDC perspective. Dent Abstr. 1998;108-110.

7. http://journals.sagepub.com/doi/pdf/10.1177/204209861455 4919

8. Dar-Odeh NS, Abu-Hammad OA, Al-Omiri MK, Khraisat AS, Shehabi AA. Antibiotic prescribing practices by dentists: A review. TherClin Risk Manag. 2010;6:301-6.

9. Thomas DW, Satterthwarte J, Absi EG, et al. Antibiotic prescription for acute dental conditions in the primary care setting. British Dental Journal. 1996;181:401-4.

10. Newman MG, Takei H, Klokkevold PR, Carranza FA. Carranza's Clinical Periodontology. Elsevier Health Sciences; 2011.

11. Beliveau D, Magnusson I, Bidwell JA, Zapert EF, Aukhil I, Wallet SM, et al. Benefits of Early Systemic Antibiotics in Localized Aggressive Periodontitis. A Retrospective Study. J ClinPeriodontol 2012;39:1075-81.

12. Department of Health UK five year antimicrobial resistance strategy 2013 to 2018 .

https://www.gov.uk/government/publications/uk-5-yearantimicrobial-resistance-strategy-2013-to-2018 